\title{
PHASE-PURE MULLITE PROPPANT FROM CALCINED FLINT CLAY WITH A DOLOMITE CONTENT
}

\author{
FAZNO ČISTI MULITNI PROPANTI IZ KALCINIRANE \\ KREMENOVE GLINE Z VSEBNOSTJO DOLOMITA
}

\author{
Mei Qin', Yaqiao Wu ${ }^{1 *}$, Kaiyue Wang1, Yuming Tian ${ }^{1,2}$, Guomin Li $^{1}$ \\ ${ }^{1}$ School of Materials Science and Engineering, Taiyuan University of Science and Technology, No. 66 Waliu Road, 030024 Taiyuan, China \\ ${ }^{2}$ Shanxi Engineering Vocational College, No. 131, Xinjian Road, 030009 Taiyuan, China \\ Prejem rokopisa - received: 2019-02-11; sprejem za objavo - accepted for publication: 2019-04-24
}

doi:10.17222/mit.2019.039

In this work, a phase-pure mullite proppant was prepared from calcined flint clay with a dolomite content at $1400{ }^{\circ} \mathrm{C}$. The phase composition and microstructure of proppant samples were investigated through X-ray diffraction and scanning electron microscopy. In addition to the apparent density, the breakage ratio was systematically investigated as a function of the content of dolomite. The results showed that the addition of dolomite went against the formation of cristobalite and promoted amorphous $\mathrm{SiO}_{2}$ to react with $\mathrm{Al}_{2} \mathrm{O}_{3}$ to form mullite. Additionally, when the content of dolomite was $4 \%$ of mass fractions, the breakage ratio of the pure-mullite ceramic proppant was the lowest, under $52 \mathrm{MPa}$. The observation that, in the presence of dolomite, calcined flint clay can act as a precursor material for phase-pure mullite is of great industrial significance.

Keywords: calcined flint clay, mullite, cristobalite, dolomite

V članku avtorji opisujejo pripravo fazno čistih mulitnih propantov (keramičnih kroglic, ki vzdržujejo ustvarjene razpoke, nastale med postopkom hidravličnega lomljenja kamenine pri pridobivanju mineralnega olja oz. nafte). Pripravljali so jih iz pri $1400{ }^{\circ} \mathrm{C}$ žgane gline $\mathrm{z}$ določeno vsebnostjo dolomita. Fazno sestavo in mikrostrukturo vzorcev propantov so preiskovali s pomočjo rentgenske difrakcije in vrstične elektronske mikroskopije. Dodatno so navidezno gostoto in lomno razmerje sistematično raziskovali v odvisnosti od vsebnosti dolomita. Rezultati so pokazali, da dodatek dolomita povzroča tvorbo kristobalita in pospešuje tvorbo mulita preko reakcije amorfnega $\mathrm{SiO}_{2} \mathrm{z} \mathrm{Al}_{2} \mathrm{O}_{3}$. Ko je bila vsebnost dolomita 4 masne \%, je bilo lomno razmerje čistih mulitnih keramičnih propantov najnižje in sicer pod $52 \mathrm{MPa}$. Ugotovitev, da kalcinirana glina $\mathrm{v}$ prisotnosti dolomita deluje kot izhodni material (prekurzor) za fazno čisti mulit, ima veliko industrijsko vrednost.

Ključne besede: kalcinirana glina, mulit, kristobalit, dolomit

\section{INTRODUCTION}

Hydraulic fracturing is operated by injecting a proppant slurry into the underground at a high rate and pressure, hence creating fractures and then keeping them open. When the hydraulic pressure is removed and the liquid returns, the proppants remain in the fractures and hold them open, thus improving the oil and gas fracture conductivity and the coefficient of mining. ${ }^{1-2}$ Routinely, compared with quartz sand, ceramic proppants are adopted in the field of hydraulic fracturing due to their outstanding characteristics such as low density, ${ }^{3-4}$ high strength and acid resistance. ${ }^{5-7}$ In the previous research works, ceramic proppants were mainly prepared from high-alumina bauxite $\left(>60 w / \% \quad \mathrm{Al}_{2} \mathrm{O}_{3}\right)$ at a high sintering temperature. ${ }^{8-10}$ Unfortunately, over-exploitation made high-grade bauxite ore less available, thereby boosting its price. In addition, new supplies of oil in the market are mainly sourced from unconventional resources such as shale oil, low-permeability rock and deep wells which drive up the production cost due to the difficulties of these processes, and put a greater pressure

*Corresponding author's e-mail:

wuyaqiao123@126.com on the environment. Therefore, it is urgent to seek a low-cost raw material to decrease the manufacturing cost of ceramic proppants.

A high melting point, better chemical inertness, low thermal-expansion coefficient and high refractoriness make mullite a favorable material for aerospace applications, ${ }^{11}$ refractories, ceramic materials ${ }^{12-13}$ and ceramic proppants. ${ }^{4,14}$ Mullite ceramic is an appropriate candidate for corundum-mullite proppants because its raw material is cheap and the performances of these proppants meet the standard requirements of petroleum and natural-gas industry standards (SY/T 5108-2014). In recent years, many researches have focused on the exploitation of the mullite raw material. For instance, E.Nsiah-Baafi et al. ${ }^{15}$ reported that mullite was fabricated from lithomargic clay using spark-plasma sintering without an addition of clay binder. M. Yan et al. ${ }^{16}$ reported that mullite was successfully prepared using bauxite with a Fe-rich oxide content $\left(\mathrm{Fe}_{2} \mathrm{O}_{3} \geq 5.0\right.$ w/\% $)$ that was left unused and abandoned anywhere. Phasepure mullite was obtained from kaolinite with $\mathrm{K}_{2} \mathrm{CO}_{3}$ by A. Yamuna. ${ }^{17} \mathrm{X}$. Wu et al. ${ }^{5}$ prepared mullite-based ceramic proppants from fly ash.

Among different grades of bauxite, flint clay is a promising material. To the best of our knowledge, there 
are few reports on mullite ceramic proppants prepared with flint clay. Additionally, the phase compositions of ceramic proppants prepared with low-grade bauxite are generally mullite and cristobalite. Considering that the $\alpha \rightarrow \beta$ transition of a cristobalite formation generates stress and causes cracking during the temperature cycling, phase-pure mullite ceramic would be a better choice when selecting the low-grade bauxite as the starting material. Therefore, we employed calcined flint clay as the main raw material and dolomite as the addition to prepare phase-pure mullite ceramic proppants. Furthermore, the phase composition, microstructure and mechanical properties of proppant samples were investigated as a function of the content of dolomite.

\section{EXPERIMENTAL PART}

\subsection{Materials}

Natural flint clay, calcined flint clay and dolomite were purchased from the city of Yangquan in the Shanxi Province, China. Calcined flint clay, obtained with sintering at $1100-1200{ }^{\circ} \mathrm{C}$ for $2 \mathrm{~h}$ in a vertical kiln, was used as the main starting material to manufacture mullite. Dolomite $\left(\mathrm{CaCO}_{3} \cdot \mathrm{MgCO}_{3}\right)$ was a kind of carbonate mineralizer boosting mullitization at a low temperature. Calcined flint clay contained $45.5 \mathrm{w} / \% \quad \mathrm{Al}_{2} \mathrm{O}_{3}$, $37.3 w / \% \mathrm{SiO}_{2}, 2.6 w / \% \mathrm{TiO}_{2}, 2.2 w / \% \mathrm{Fe}_{2} \mathrm{O}_{3}$ and 12.4 $w / \%$ ignition loss. Dolomite contained $30.4 w / \% \mathrm{CaO}$, $21.7 w / \% \mathrm{MgO}$ and $47.9 w / \%$ ignition loss.

\subsection{Preparation of proppants}

The flow chart of the ceramic-proppant preparation is shown in Figure 1. Firstly, massive ore was crashed up with a Kibbler and a globe mill. After drying, fine power was crushed and passed through a sieve with a 100-mesh aperture size. Secondly, a strong mixing machine (R02, Eirich Co. Ltd., Germany) was used to create spherical green bodies. These were passed through a set of sieves of 20/40 meshes (aperture size of $0.85-0.43 \mathrm{~mm}$ ). After the sifting, green proppant particles were dried in a drying baker and then sintered in an electric furnace (Xiangke SX3-12-16, Xiangtan Instrument Technology Co. Ltd., China) at variant temperatures $(1350,1400$, 1450 and 1500$)^{\circ} \mathrm{C}$, respectively) in air for $2 \mathrm{~h}$, at a heating rate of $5{ }^{\circ} \mathrm{C} / \mathrm{min}$, followed by furnace cooling. Thirdly, ceramic proppants were separated again with a sieving machine. Lastly, utilizing a universal tester, $\mathrm{XRD}, \mathrm{SEM}$ and other procedures, we tested the characteristics of ceramic proppants.

\subsection{Characterization}

A thermogravimetric analysis (TGA) and differential scanning calorimetry (DSC), which are used in the material and energy sciences to determine the weight variation, heat-absorption capacity and heat-release capacity, allow mineral decompositions or reactions to be observed graphically through peaks or valleys. ${ }^{18}$ Natural flint clay was investigated using the TGA/DSC $3^{+}$STA Re System (METTLER TOLEDO). The temperature scanning program was performed at a scanning rate of $10{ }^{\circ} \mathrm{C} \cdot \mathrm{min}^{-1}$ in a temperature range of $30-1500{ }^{\circ} \mathrm{C}$ under

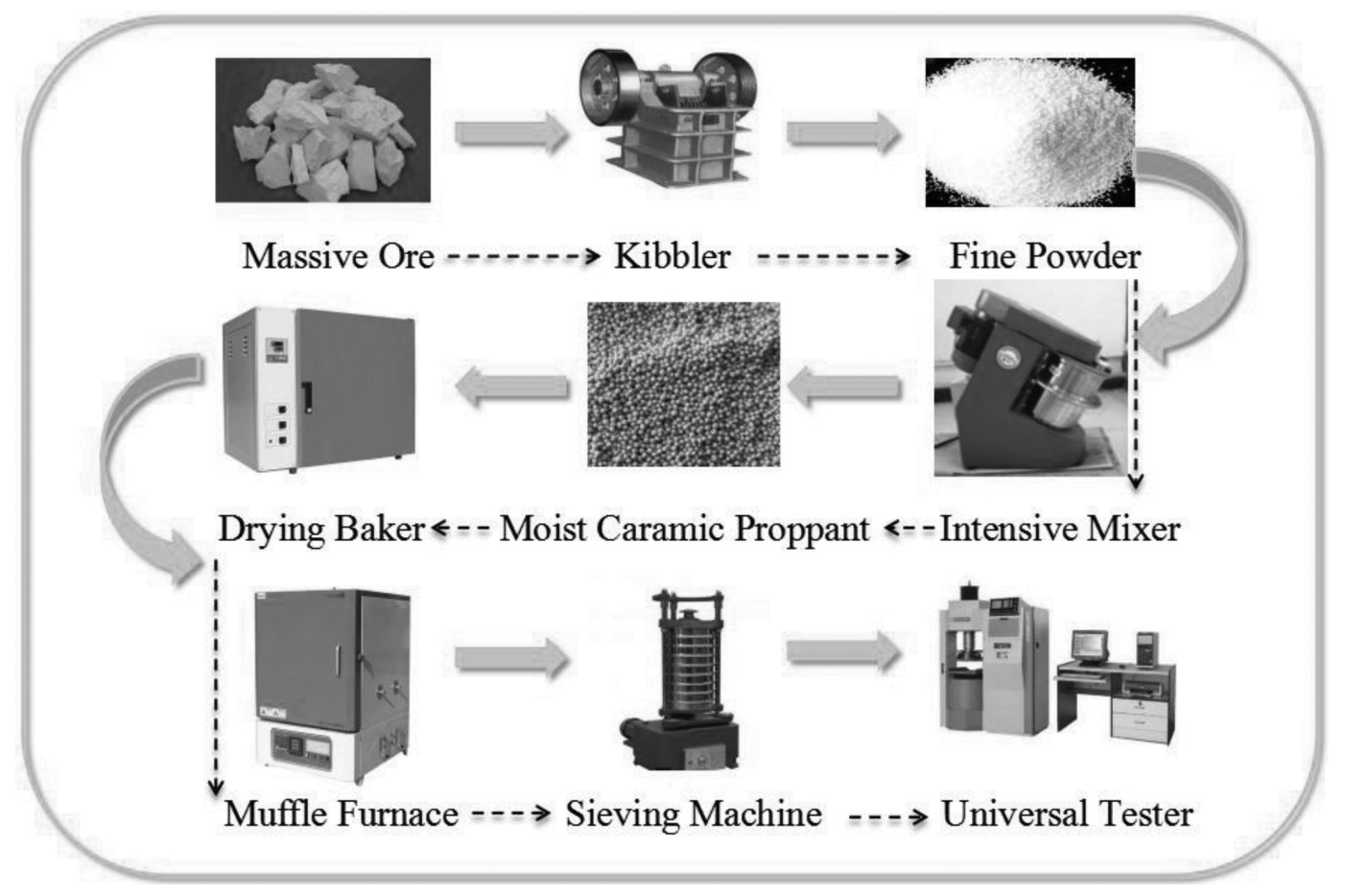

Figure 1: Flow chart of preparing ceramic proppants 

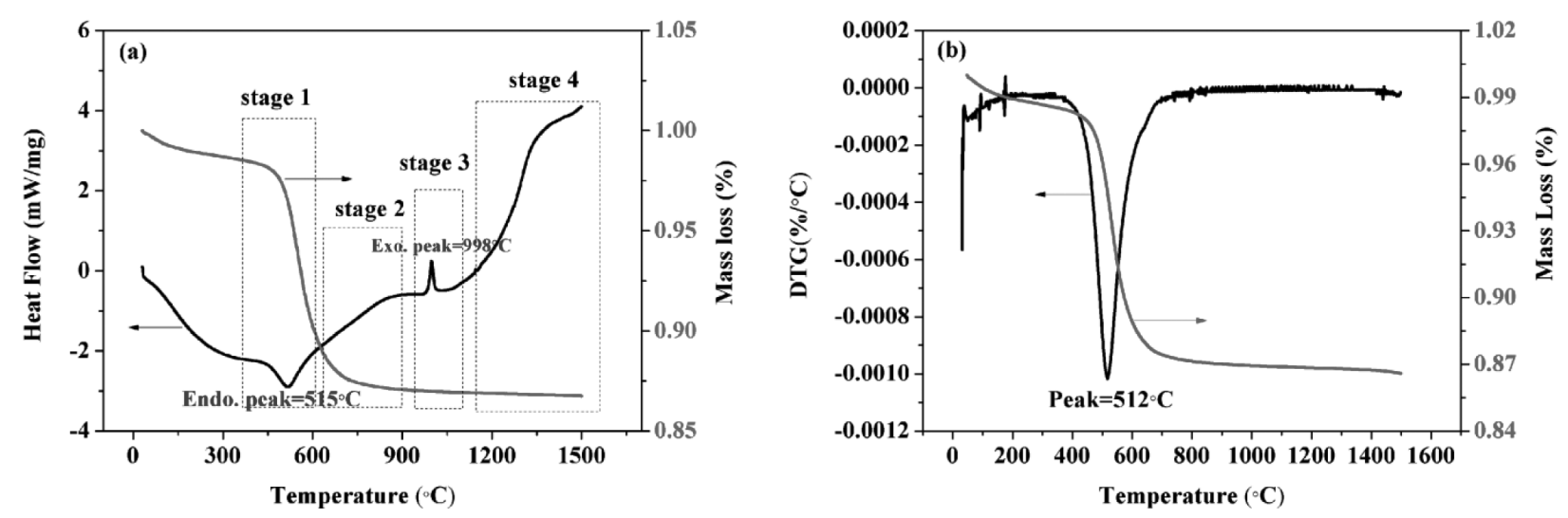

Figure 2: a) Thermoanalysis (DSC-TG), b) DTG-TG results for natural flint clay at argon atmospheres with a heating rate of $10{ }^{\circ} \mathrm{C} \cdot \mathrm{min}^{-1}$

an argon purge of $20 \mathrm{~mL} \cdot \mathrm{min}^{-1}$. The phase compositions of the proppant samples were identified with powder X-ray diffraction (XRD, X'Pert PRO; Philips Co. Ltd., Holland) utilizing Ni-filtered $\mathrm{Cu} K_{\alpha}$ radiation with a scanning speed of $0.02 \%$ step. The microstructures of proppants were examined with a field emission scanning electron microscope (FESEM, S-4800; Hitachi, Japan).

\section{RESULTS AND DISCUSSION}

Thermal-analysis techniques, such as thermogravimetry (TG), differential thermal analysis (DTA), differential scanning calorimetry (DSC) and derivative thermogravimetry (DTG) were widely applied when studying the thermal behavior and structure of inorganic compounds, complexes and coordination polymers of transition metal ions. ${ }^{19-21}$ In this work, natural flint clay was the basic material, exhibiting a typical thermal behavior. So, a close investigation of DSC/TG/DTG curves (Figure 2) of natural flint clay was conducted and the result revealed the thermal-decomposition profile, which occurs through four steps, except the initial step of the evaporation of absorbed water. Thermal decomposition of natural flint clay was carried out under an argon atmosphere at a heating rate of $10{ }^{\circ} \mathrm{C} \cdot \mathrm{min}^{-1}$ over the temperature range $30-1500{ }^{\circ} \mathrm{C}$. In addition, the phase composition of natural flint clay was identified with X-ray powder diffraction. The XRD pattern is shown in Figure 3. Diffraction peaks were indexed, indicating that the mineral phase was kaolinite $\left(\mathrm{Al}_{2} \mathrm{O}_{3} \cdot 2 \mathrm{SiO}_{2} \cdot 2 \mathrm{H}_{2} \mathrm{O}\right.$ PDF no. 14-0164).

The phase transition of kaolinite was systematically investigated in previous research. ${ }^{22}$ Phase transformations were expressed in the form of chemical reactions for the ease of explanation. The first stage of degradation took place at $400-600{ }^{\circ} \mathrm{C}$ with $\mathrm{T}_{\mathrm{DTG}}$ at $512{ }^{\circ} \mathrm{C}$ and an endothermic peak at $515^{\circ} \mathrm{C}$ due to the removal of constitutional water, yielding anhydrous intermediate metakaolin $\mathrm{Al}_{2} \mathrm{O}_{3} \cdot 2 \mathrm{SiO}_{2}$. At a higher temperature of $600-900{ }^{\circ} \mathrm{C}$, this intermediate underwent further degradation, producing spinel-type phase $2 \mathrm{Al}_{2} \mathrm{O}_{3} \cdot 3 \mathrm{SiO}_{2}$ and discarding amorphous silicon. The third stage of degradation was at
930-1100 ${ }^{\circ} \mathrm{C}$ with an exothermic peak at $998{ }^{\circ} \mathrm{C}$, as shown in Figure 2a. The spinel-type structure transformed to mullite initial phase $\mathrm{Al}_{2} \mathrm{O}_{3} \cdot \mathrm{SiO}_{2}$, further discarding amorphous silicon. ${ }^{23,24}$ In a range of 1100-1500 ${ }^{\circ} \mathrm{C}$, the amorphous silicon transformed into cristobalite and mullite $3 \mathrm{Al}_{2} \mathrm{O}_{3} \cdot 2 \mathrm{SiO}_{2}$ developed from $\mathrm{Al}_{2} \mathrm{O}_{3} \cdot \mathrm{SiO}_{2}$, as expressed with stage $4 .{ }^{25}$

$$
\begin{gathered}
\mathrm{Al}_{2} \mathrm{O}_{3} \cdot 2 \mathrm{SiO}_{2} \cdot 2 \mathrm{H}_{2} \mathrm{O} \underset{400-600{ }^{\circ} \mathrm{C}}{\longrightarrow} \\
\mathrm{Al}_{2} \mathrm{O}_{3} \cdot 2 \mathrm{SiO}_{2} \cdot 2 \mathrm{H}_{2} \mathrm{O} \\
2\left(\mathrm{Al}_{2} \mathrm{O}_{3} \cdot 2 \mathrm{SiO}_{2}\right) \stackrel{600-900{ }^{\circ} \mathrm{C}}{\longrightarrow} \\
2 \mathrm{Al}_{2} \mathrm{O}_{3} \cdot 2 \mathrm{SiO}_{2}+2 \mathrm{SiO}_{2} \text { (amorphous) } \\
2 \mathrm{Al}_{2} \mathrm{O}_{3} \cdot 3 \mathrm{SiO}_{2} \underset{930-1100{ }^{\circ} \mathrm{C}}{\longrightarrow} \\
2\left(\mathrm{Al}_{2} \mathrm{O}_{3} \cdot 2 \mathrm{SiO}_{2}\right)+2 \mathrm{SiO}_{2} \text { (amorphous) } \\
3\left(\mathrm{Al}_{2} \mathrm{O}_{3} \cdot 2 \mathrm{SiO}_{2}\right) \stackrel{1100-1500{ }^{\circ} \mathrm{C}}{\longrightarrow} \\
3 \mathrm{Al}_{2} \mathrm{O}_{3} \cdot 2 \mathrm{SiO}_{2}(\text { mullite })+\mathrm{SiO}_{2} \text { (cristobalite) }
\end{gathered}
$$

Therefore, in our work, the samples were first heated to $500{ }^{\circ} \mathrm{C}$ at $10^{\circ} \mathrm{C} \mathrm{min}^{-1}$, and then to $1100-1500{ }^{\circ} \mathrm{C}$ at 5 ${ }^{\circ} \mathrm{C} \cdot \mathrm{min}^{-1}$ to promote metakaolin degradation and produce the mullite initial phase $\mathrm{Al}_{2} \mathrm{O}_{3} \cdot \mathrm{SiO}_{2}$. Moreover, the sintering temperature was defined to be higher than

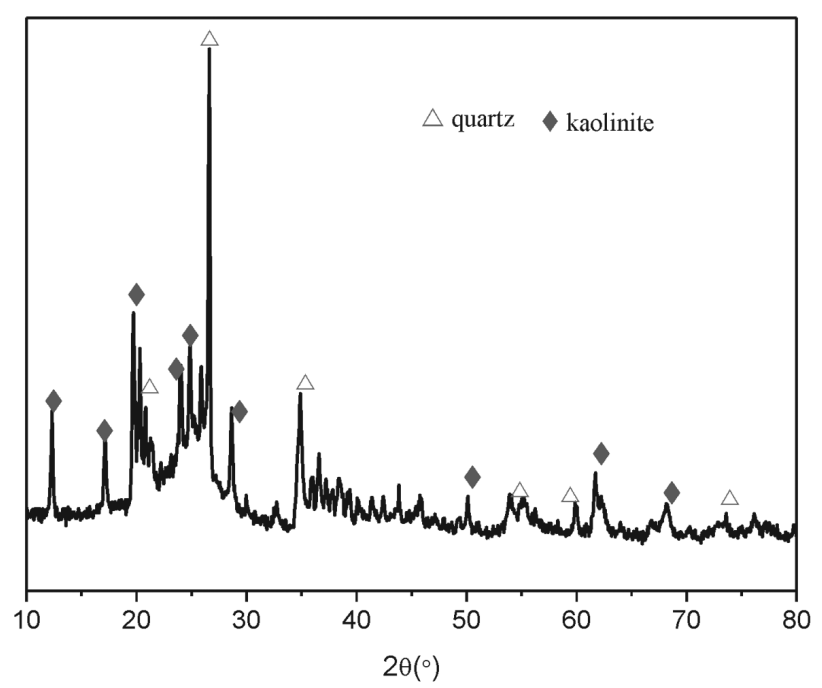

Figure 3: XRD patterns of natural flint clay 
$1100{ }^{\circ} \mathrm{C}$ and held for $2 \mathrm{~h}$ to obtain a high-strength and high-toughness mullite phase.

The X-ray diffraction patterns of the proppants prepared with calcined flint clay at different temperatures and the proppants prepared with calcined flint clay including different amounts of dolomite at $1400{ }^{\circ} \mathrm{C}$ are presented in Figure 4.

As shown in Figure $\mathbf{4 a}$, the crystalline phase of the proppants sintered at different temperatures (1350-1450 $\left.{ }^{\circ} \mathrm{C}\right)$ contained mullite $\left(3 \mathrm{Al}_{2} \mathrm{O}_{3} \cdot 2 \mathrm{SiO}_{2} \mathrm{PDF}\right.$ no. 15-0776) and cristobalite $\left(\mathrm{SiO}_{2} \mathrm{PDF}\right.$ no. 82-0512). The phase compositions of every sample with different sintering temperatures were the same except the content of the crystalline phase. In detail, the peak relative height gradually increased and the values of the full width at half-maximum (FWHM) of every peak gradually decreased with the increased firing temperature. In addition, the overlapped diffraction peak located at $25^{\circ} \leq 2 \theta \leq 27^{\circ}$ was distinctly divided into two
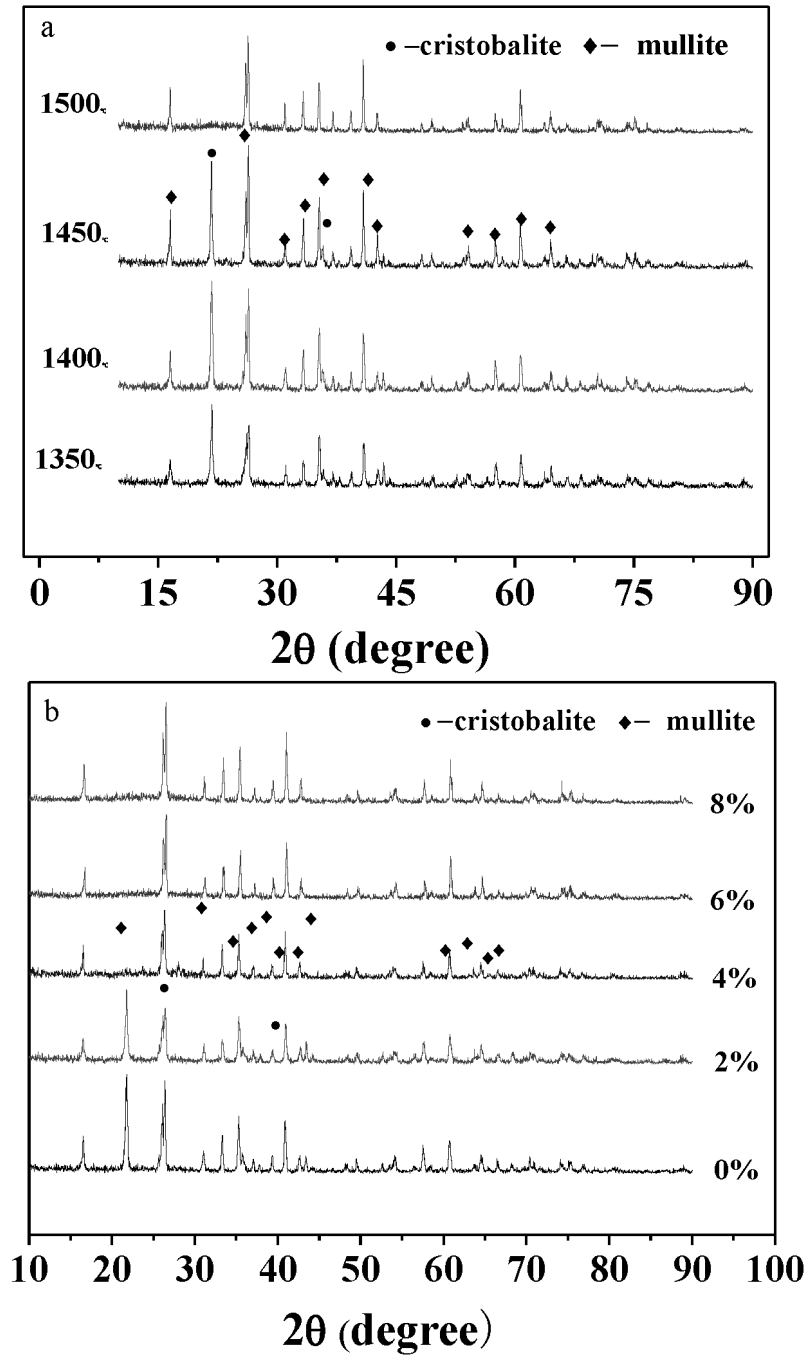

Figure 4: X-ray diffraction patterns of: a) proppants prepared with calcined flint clay at different temperatures,b) proppants prepared with calcined flint clay with different amounts of dolomite at $1400{ }^{\circ} \mathrm{C}$ diffraction peaks obtained from the (120) and (210) crystal planes of mullite, along with the increase in the temperature. This indicates that the elevated sintering temperature was prone to cause the development of a crystalline phase. The phase evolution in the proppants was related to stage 4 as shown in Figure 2a. When the sintering temperature was up to $1500{ }^{\circ} \mathrm{C}$, mullite was still present but cristobalite disappeared as shown in Figure 4a.

When adding dolomite, the phase composition changed with different additive amounts of dolomite at $1400{ }^{\circ} \mathrm{C}$ as shown in Figure $\mathbf{4 b}$. When the amount was more than or equal to $4 w / \%$, mullite was still present but cristobalite disappeared. The disappearing of cristobalite in calcined flint clay and the presence of dolomite can be explained as follows.

In our work, when the material used was calcined flint clay and the sintering temperature was $1500{ }^{\circ} \mathrm{C}$, cristobalite transformed into a quartzose fused mass, quartzose glass and then reacted with $\mathrm{Al}_{2} \mathrm{O}_{3}$ to form mullite, resulting in the disappearing of the cristobalite diffraction maximum. Therefore, double firing was used to prepare phase-pure mullite from calcined flint clay at the expense of energy.

The purpose of dolomite accession is to introduce $\mathrm{CaO}$ and $\mathrm{MgO}$. During the sintering process, the additive could largely increase the degree of mullitization, which can be verified with the SEM photographes included in Figure 5. The reason for this is the fact that the $\mathrm{MgO}-\mathrm{CaO}-\mathrm{Al}_{2} \mathrm{O}_{3}-\mathrm{SiO}_{2}$ system had a lower eutectic point than the $\mathrm{CaO}-\mathrm{Al}_{2} \mathrm{O}_{3}-\mathrm{SiO}_{2}$ ternary system. With a dolomite increase, more liquid phase appeared at a lower temperature. On the one hand, it provided a favorable environment for a nucleus development and grain growth. On the other hand, it facilitated the second mullitization, based on the fact that $\mathrm{Al}_{2} \mathrm{O}_{3}$ reacts with the silica-rich liquid phase. ${ }^{26}$ Thereby, cristobalite disappeared due to the mullitization.

The disappearing of cristobalite is helpful for the performance of proppants. It is because of the crystal phase transition of cristobalite. This leads to a serious volumetric change and even cracking of the ceramic body. Upon cooling, $\beta$-cristobalite turns into its tetragonal $\alpha$ phase at $270{ }^{\circ} \mathrm{C} . \alpha$ - and $\beta$-cristobalite have the average bulk thermal expansion values of 91.7 and $6 \times 10^{-6} \mathrm{~K}^{-1}$, respectively. Such remarkably different thermal dilations affect the shrinkage upon cooling of the ceramic bodies, therefore having a relevant effect on the quality of the final product. ${ }^{27}$

The cross-sections of proppant specimens with different amounts of dolomite at $1400{ }^{\circ} \mathrm{C}$ are depicted in Figure 5. The enlargement factor of every SEM image is 10,000 times. As seen in Figure 5a (without dolomite), a small amount of acicular mullite and a small number of large pores were observed. With the addition of dolomite (Figure 5b), a large amount of rod-shaped mullite occurred, and the size of mullite grains increased. In Fig- 


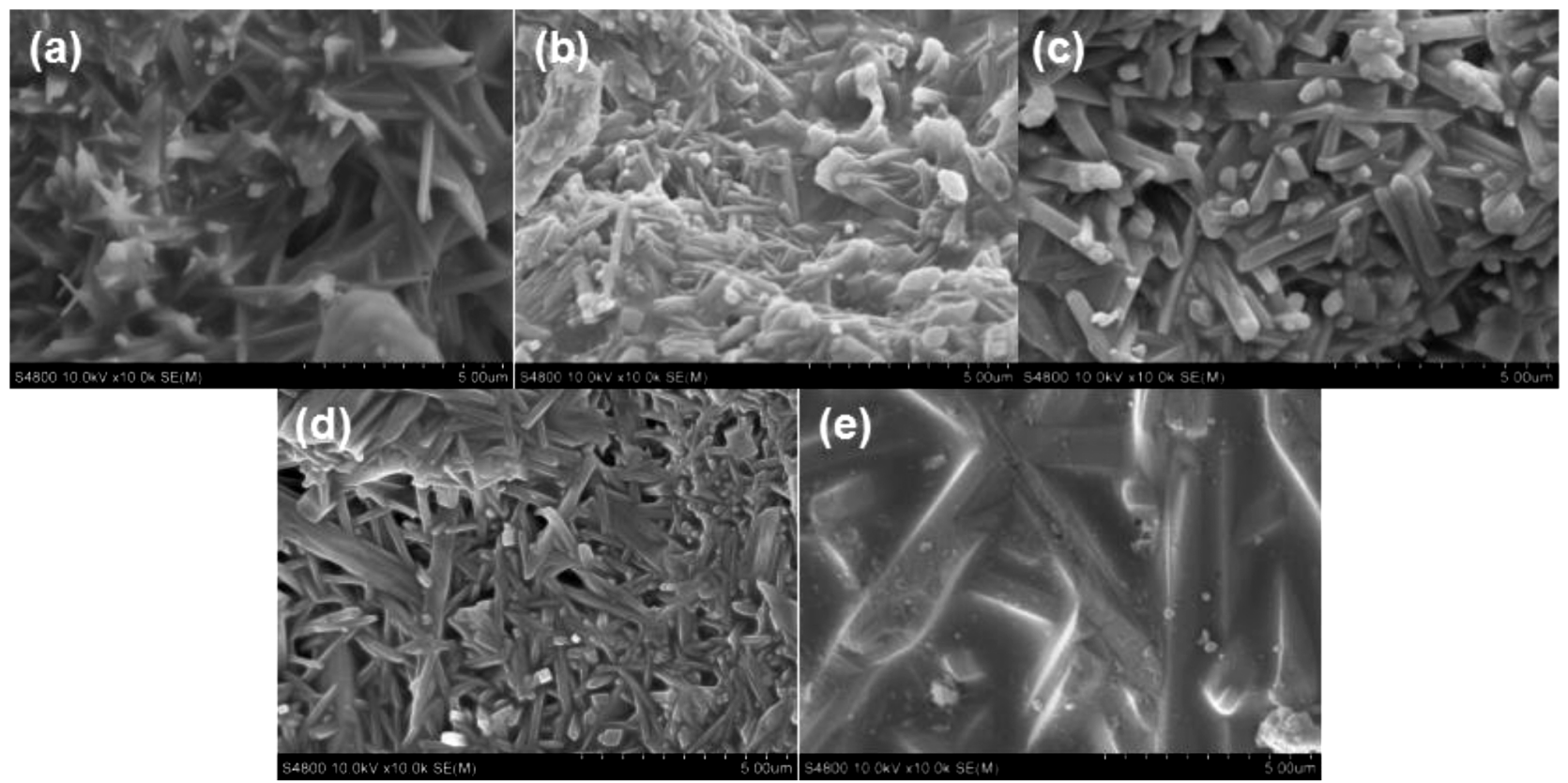

Figure 5: Morphology of proppants with different amounts of dolomite at $1400{ }^{\circ} \mathrm{C}:$ a) $0 w / \%$, b) $2 w / \%$, c) $4 w / \%$, d) $6 w / \%$, e) $8 w / \%$

ure $5 \mathbf{c}$ (with 4 w/\% dolomite), the mullite regrew into a network structure, and the samples exhibited a compact structure. When the addition of dolomite accounted for 6 $w / \%$ ( Figure 5d), the crystal boundaries between the mullite grains began to melt and became obscure due to the generation of the liquid phase. Figure 5e shows that the generation of an excessive liquid phase caused an abnormal growth of the mullite grains. In a word, mullite grows up with increased amounts of dolomite, indicating that dolomite provides a strong driving force for the crystal growth of mullite.

The apparent density of proppants can be calculated with the following Equation (1):

$$
\rho_{\mathrm{A}}=\frac{M_{\mathrm{p}}}{\left[V_{\mathrm{b}}-\left(M-M_{\mathrm{b}}-M_{\mathrm{p}}\right) / \rho_{\mathrm{w}}\right]}
$$

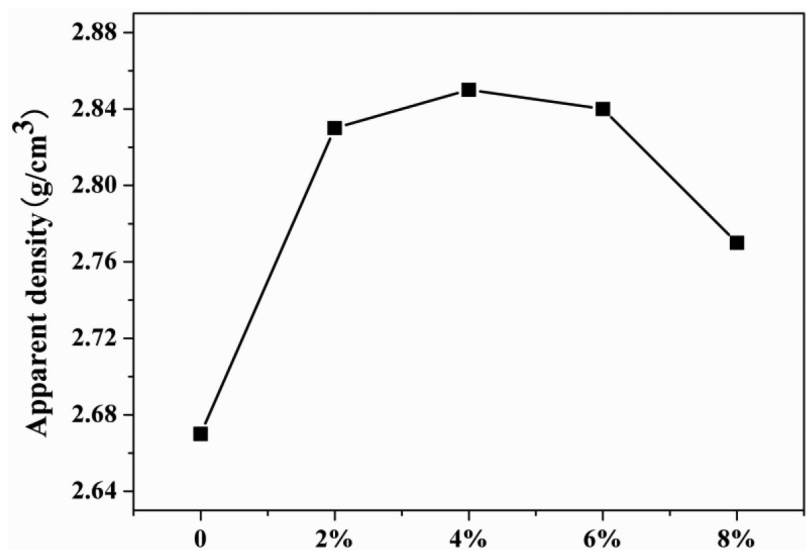

Figure 6: Apparent density of proppants prepared with calcined flint clay with different amounts of dolomite at $1400{ }^{\circ} \mathrm{C}$ where $M$ is the weight of the density bottle including the samples and water, $M_{\mathrm{b}}$ is the weight of the density bottle, $M_{\mathrm{p}}$ is the weight of the samples, $\rho_{\mathrm{w}}$ is the density of the water, and $V_{\mathrm{b}}$ is the volume of the density bottle. Figure 6 displays the variation of the apparent density of the proppants prepared with calcined flint clay with different amounts of dolomite at $1400{ }^{\circ} \mathrm{C}$. The results show an abruptly increasing trend with the 2 w/\% addition of dolomite. Then the apparent density moves into a lightly ascending stage as the addition of dolomite increases from $2 w / \%$ to $6 w / \%$. However, it declines after the addition of dolomite is raised to $8 \mathrm{w} / \%$. This phenomenon is consistent with the morphology of the samples. Comparing Figure 5a (without an addition of dolomite) with Figure 5b (with an addition of 2 w/\% dolomite), it can be seen that the macropores disappear and there are small pores derived from the interleaving of the mullite growth. With the addition of $8 w / \%$ dolomite, the mullite grew up abnormally due to the generation of the excessive liquid phase. Large pores or an excessive growth of mullite grains were detrimental to the strength. ${ }^{4}$

The mechanical strength, expressed with the breakage ratio, is one of the significant factors for proppants. It is the resulting property affected by many factors such as the phase composition, porosity, apparent density, distribution of crystals and so on. The breakage ratio is expressed with the following formula: $\eta=M_{\mathrm{c}} / M_{0} \times 100$ $\%$, where $M_{\mathrm{c}}$ is the weight of crushed specimens after testing and $M_{0}$ is the weight of the specimens before testing. This property was tested and the results are shown in Figure 6. The breakage ratio decreases with the addition of dolomite up to $4 w / \%$ followed by an increase in the breakage ratio with the addition of 


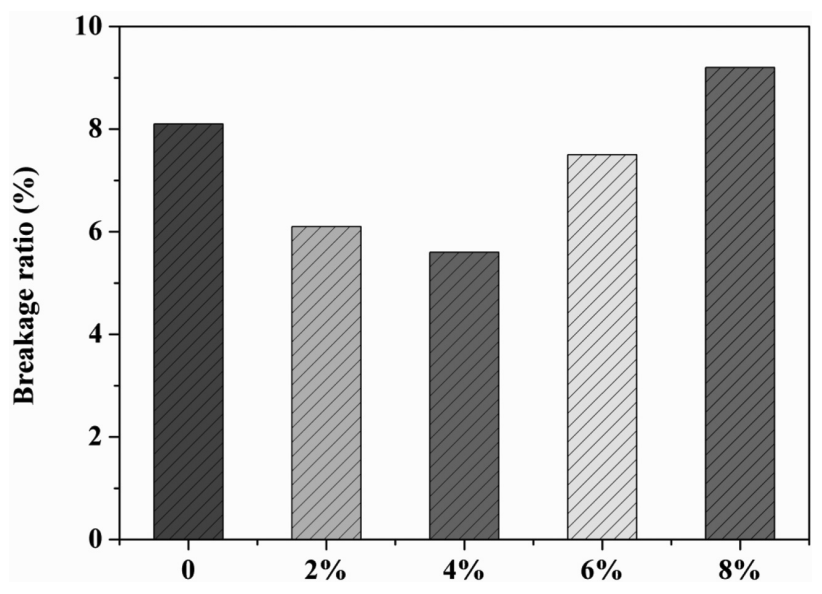

Figure 7: Breakage ratio of proppants prepared with calcined flint clay with different amounts of dolomite at $1400{ }^{\circ} \mathrm{C}$ under $52-\mathrm{MPa}$ pressure

dolomite up to $8 w / \%$. It is suggested that $4 w / \%$ is the optimum addition.

Through Figures 5, 6 and 7, it can be seen that the mechanical strength of the proppants was strongly affected by the size of the rod-shaped mullite and the apparent density of the proppants. A smaller size of the rod-shaped mullite and a higher apparent density produce a higher mechanical strength. Dolomite can facilitate the mullite formation, but it can also make mullite rods grow abnormally. A big size of the rod-shaped mullite is bad for the mechanical strength of proppants. Additionally, dolomite decomposes into the $\mathrm{CO}_{2}$ gas at a higher temperature, yielding a lot of pores, and thus decreasing the apparent density of proppants. The lower the apparent density, the lower is the mechanical strength.

\section{CONCLUSIONS}

In this work, low-cost and low-density ceramic proppants were prepared from calcined flint clay with a dolomite content at $1400{ }^{\circ} \mathrm{C}$. XRD patterns and SEM images indicated that taking the calcined flint clay as the raw material is helpful for cristobalite to enter the vitreous phase, react with aluminium oxide and produce mullite at $1500{ }^{\circ} \mathrm{C}$. Besides, adding a certain amount of dolomite into the calcined flint clay inhibits the cristobalite growth. The phase transition of cristobalite at about $270{ }^{\circ} \mathrm{C}$ induces a significant change in the coefficient of heat expansion and a decrease in the mechanical strength of ceramic proppants. Thus, calcined flint clay including a certain amount of dolomite is a better option for preparing phase-pure mullite ceramic. Above all, low-cost and high-quality ceramic proppants prepared with calcined flint clay and a certain amount of dolomite can serve as a possible alternative to the material made from high-grade bauxite to be applied in 52-MPa hydraulic-fracturing operations.

\section{Acknowledgment}

This work was supported by the Major Science and Technology Project in the Shanxi Province (grant number 20181101001); the Talents Training Project of the Shanxi Graduate Joint Training Base in China (grant numbers 2017JD33, 2018JD34); the Shanxi Province Science Foundation for Youths (grant number 201801D221119); the Shanxi Province Key Subjects Construction in China and the Collaborative Innovation Centre of the Shanxi Province Key Basic Materials in China.

\section{REFERENCES}

${ }^{1}$ N. V. Queipo, A. J. Verde, J. Canelon, S. Pintoset, Efficient global optimization for hydraulic fracturing treatment design, J. Pet. Sci. Eng., 35 (2002) (3-4), 151-166, doi:10.1016/S0920-4105(02) 00237-1

${ }^{2}$ S. Ouyang, G. F. Carey, C. H. Yew, An adaptive finite element scheme for hydraulic fracturing with proppant transport, Int. J. Numer. Methods Fluids, 24 (1997) 7, 645-670

${ }^{3}$ J. Hao, H. Ma, X. Feng, K. Wang, Y. Tian, Y. Chai, Microstructure and fracture mechanism of low density ceramic proppants, Mater. Lett., 213 (2018), 92-94, doi:10.1016/j.matlet.2017.11.021

${ }^{4}$ J. Zhao, Z. Liu, Y. Li, Preparation and characterization of low-density mullite-based ceramic proppant by a dynamic sintering method, Mater. Lett., 152 (2015), 72-75, doi:10.1016/j.matlet.2015.03.060

${ }^{5}$ X. Wu, Z. Huo, Q. Ren, H. Li, F. Lin, T. Wei, Preparation and characterization of ceramic proppants with low density and high strength using fly ash, J. Alloys Compd., 702 (2017), 442-448, doi:10.1016/ j.jallcom.2017.01.262

${ }^{6} \mathrm{~T}$. Wu, B. Wu, S. Zhao, Acid resistance of silicon-free ceramic proppant, Mater. Lett., 92 (2013), 210-212, doi:10.1016/j.matlet. 2012.10.124

${ }^{7}$ T. Wu, J. Zhou, B. Wu, Effect of $\mathrm{TiO}_{2}$ content on the acid resistance of a ceramic proppant, Corros. Sci., 98 (2015), 716-724, doi:10.1016/j.corsci.2015.06.012

${ }^{8}$ Z. Liu, J. Zhao, Y. Li, Z. Zeng, J. Mao, Y. Peng, Y. He, Low-temperature sintering of bauxite-based fracturing proppants containing $\mathrm{CaO}$ and $\mathrm{MnO}_{2}$ additives, Mater. Lett., 171 (2016), 300-303, doi:10.1016/j.matlet.2016.02.090

${ }^{9}$ A. Assem, H. Nasr-El-Din, Interactions between different acids and bauxitic-based ceramic proppants used in gravel-packed and fractured wells, J. Petrol. Sci., 158 (2017), 441-453, doi:10.1016/ j.petrol.2017.08.075

${ }^{10}$ X. Ma, Y. Tian, Y. Zhou, K. Wang, Y. Chai, Z. Li, Sintering temperature dependence of low-cost, low-density ceramic proppant with high breakage resistance, Mater. Lett., 180 (2016), 127-129, doi:10.1016/ j.matlet.2016.04.080

${ }^{11}$ P. Sarin, W. Yoon, R. Haggerty et al., Effect of transition-metal-ion doping on high temperature thermal expansion of 3:2 mullite-An in situ, high temperature, synchrotron diffraction study, J. Eur. Ceram. Soc., 28 (2008) 2, 353-365, doi:10.1016/j.jeurceramsoc.2007.03.002

${ }^{12}$ W. E. Cameron, Mullite: a substituted alumina, Am. Mineral., 62 (1977), 747-755

${ }^{13}$ S. Aryal, P. Rulis, W. Y. Ching, Mechanical properities and electronic structures of mullite phases using first-principles modeling, J. Am. Ceram. Soc., 95 (2012) 7, 2075-2088

${ }^{14}$ X. Chen, T. Li, Q. Ren, X. Wu, A. Dang, H. Li, T. Zhao, Fabrication and morphology control of high strength light weight mullite whisker network, J. Alloys Compd., 729 (2017), 285-292, doi:10.1016/ j.jallcom.2017.09.150 


\section{QIN et al.: PHASE-PURE MULLITE PROPPANT FROM CALCINED FLINT CLAY WITH A DOLOMITE CONTENT}

${ }^{15}$ E. Nsiah-Baafi, A. Andrews, Fabrication of mullite from lithomargic clay via spark plasma sintering, Ceram. Int., 43 (2017) 16 14277-14280, doi:10.1016/j.ceramint.2017.07.179

${ }^{16}$ M. Yan, Y Li, Y. Sun, L. Li, S. Tong, J. Sun, Controllable preparation and synthetic mechanism of mullite from the bauxite with Fe-rich oxide content, Mater. Chem. Phys., 202 (2017), 245-250, doi:10.1016/j.matchemphys.2017.09.017

${ }^{17}$ A. Yamuna, S. Devanarayanan, M. Lalithambika, Phase-Pure Mullite from Kaolinite, J. Am. Ceram. Soc., 85 (2002) 6, 1409-1413

${ }^{18}$ P. Basinas, Y. Wu, P. Grammelis, E. J. Anthony, J. R. Lim, Effect of pressure and gas concentration on $\mathrm{CO} 2$ and $\mathrm{SO} 2$ capture performance of limestones, Fuel, 122 (2014), 236-246, doi:10.1016/ j.fuel.2014.038

${ }^{19}$ F. D. Souza, S. R. Braganca, Thermogravimetric analysis of limestones with different contents of $\mathrm{MgO}$ and microstructural characterization in oxy-combustion, Thermochim. Acta, 561 (2013), 19-25, doi:10.1016/j.tca.2013.03.006

${ }^{20}$ P. Ballester, I. Mármol, J. Morales, L. Sánchez, Use of limestone obtained from waste of the mussel cannery industry for the production of mortars, Cem. Concr. Res., 37 (2007) 4, 559-564, doi:10.1016/ j.cemconres.2007.01.004

${ }^{21}$ Y. Zhang, Q. Sun, J. Geng, Microstructural characterization of limestone exposed to heat with XRD, SEM and TG-DSC, Mater. Charact., 134 (2017), 285-295, doi:10.1016/j.matchar.2017.11.007
${ }^{22}$ A. K. Chakraborty, DTA study of preheated kaolinite in the mullite formation region, Thermochim. Acta, 398 (2003) 1-2, 203-209, doi.org/10.1016/S0040-6031(02)00367-2

${ }^{23}$ G. W. Brindley, M. Nakahira, The kaolinite-mullite reaction series: III, the high-temperature phases, J. Am. Ceram. Soc., 42 (1959) 7, 319-324

${ }^{24}$ C. Y. Chen, G. S. Lan, W. H. Tuan, Microstructural evolution of mullite during the sintering of kaolin power compacts, Ceram. Int., 26 (2000), 715-720, doi:10.1016/S0272-8842(00)00009-2

${ }^{25}$ Y. Zhang, L. Xu, S. Seetharaman, L. Liu, X. Wang, Z. Zhang, Effect of chemistry and mineral on structural evolution and chemical reactivity of coal gangue during calcinations: towards efficient utilization, Mater. Struct., 48 (2015), 2779-2793, doi:10.1617/s11527014-0353-0

${ }^{26}$ X. Xu, J. Li, J. Wu, Z. Tang, L. Chen, Y. Li, C. Lu, Preparation and thermal shock resistance of corundum-mullite composite ceramics from andalusite, Ceram. Int., 43 (2017), 1762-1767, doi:10.1016/ j.ceramint.2016.10.116

${ }^{27}$ D. Njoya, M. Hajjaji, D. Njopwouo, Effects of some processing factors on technical properties of a clay-based ceramic material, Appl. Clay Sci., 65-66 (2012), 106-113, doi:10.1016/j.clay.2012.05.013 